\title{
Leucine Kinetics during Simultaneously Administered Insulin and Dexamethasone in Preterm Infants with Severe Lung Disease
}

\author{
RON H.T. van BEEK, LUC J.I. ZIMMERMANN, JOLANDE G. VERGUNST van KEULEN, \\ VIRGILIO P. CARNIELLI, DARCOS J.L.D. WATTIMENA, JOHANNES B. van GOUDOEVER, AND \\ PIETER J.J. SAUER \\ Department of Pediatrics, Ignatius Hospital Breda, 4800 RK Breda, The Netherlands [R.H.T.v.B.]; \\ Department of Pediatrics, Division of Neonatology, Sophia Children's Hospital [L.J.I.Z., J.G.V.v.K., \\ J.B.v.G.], and Internal Medicine II [D.J.L.D.W.], Erasmus University Rotterdam, 3015 GJ Rotterdam, The \\ Netherlands; Institute of Child Health, Great Ormond Street Hospital, London WC1N 1EH, United \\ Kingdom [V.P.C.]; and Department of Pediatrics, Beatrix Children's Hospital, University Groningen, \\ 9700 RB Groningen, The Netherlands [P.J.J.S.]
}

\section{ABSTRACT}

\begin{abstract}
The objective of this study was to determine whether insulin administration would prevent the well-documented catabolic effect of dexamethasone given to preterm infants with chronic lung disease. We studied leucine metabolism in 11 very-low-birthweight infants before dexamethasone treatment and on $\mathrm{d} 2,4$, and 7 thereafter. During the first $4 \mathrm{~d}$ of dexamethasone, insulin was administered i.v. at a dose of $0.5(n=7)$ or $1.0(n=5)$ $\mathrm{IU} / \mathrm{kg} / \mathrm{d}$. Leucine turnover was not significantly different between d $0(337 \pm 41.3 \mu \mathrm{mol}$ leucine $/ \mathrm{kg} / \mathrm{h}), \mathrm{d} 2(288 \pm 27.2 \mu \mathrm{mol}$ leucine $/ \mathrm{kg} / \mathrm{h}), \mathrm{d} 4$ (302 $\pm 22.1 \mu \mathrm{mol}$ leucine $/ \mathrm{kg} / \mathrm{h})$, and d 7 (321 $\pm 21.2 \mu \mathrm{mol}$ leucine $/ \mathrm{kg} / \mathrm{h}$ ), and neither was leucine breakdown $(272 \pm 21.9 \mu \mathrm{mol}$ leucine $/ \mathrm{kg} / \mathrm{h}$ on $\mathrm{d} 0,225 \pm 21.5 \mu \mathrm{mol}$ leucine $/ \mathrm{kg} / \mathrm{h}$ on d 2, $231 \pm 21 \mu \mathrm{mol}$ leucine $/ \mathrm{kg} / \mathrm{h}$ on $\mathrm{d} 4$, and 242
\end{abstract}

$\pm 17.6 \mu \mathrm{mol} \mathrm{leucine} / \mathrm{kg} / \mathrm{h}$ on $\mathrm{d} 7)$. Weight gain rates were significantly lower during the first week of dexamethasone treatment compared with the week before treatment or the second and third week. We conclude that during insulin and corticosteroid administration in very-low-birth-weight infants, no changes were observed in leucine kinetics in contrast to previous studies. The decrease in weight gain was not reversed. (Pediatr Res 49: 373-378, 2001)
CLD, chronic lung disease
rhGH, recombinant hGH

Abbreviations:
Owing to improvements in neonatal therapies, increasing numbers of very-low-birth-weight infants are surviving. However, lung damage can occur at these low gestational ages because of the infant's underdeveloped lungs combined with a requirement for artificial ventilation at sometimes high airway pressure. Consequent respiratory complications can result in CLD. Fluid restriction and diuretics, traditionally the first line of therapy in such cases, result in lower weight gain rates, which presents a concern because of the fact that growth is essential to overcome the pulmonary problems.

Subsequent to the 1985 publication of Avery et al. (1) on the use of dexamethasone to treat respirator-dependent infants with bronchopulmonary dysplasia, corticosteroids have increasingly been used in the management of infants on respirators in an attempt to achieve extubation and lessen the development of

Received May 15, 2000; accepted October 12, 2000.

Correspondence to R.H.T. van Beek, Ignatius Ziekenhuis Breda, Molengracht 21, 4800 RK Breda, The Netherlands.
CLD. Recent studies indicate a trend toward the use of steroids at earlier postnatal ages in smaller infants $(2,3)$, whose growth is already suboptimal.

The fact that corticosteroids are catabolic has been shown in a number of studies. Not only are urea and plasma amino acid levels increased (4-10), but protein anabolism is impaired, as shown by direct measurements $(8-13)$. We conducted a study, which demonstrated that higher leucine catabolic and proteolytic rates occur when high doses of dexamethasone are administered to preterm infants with CLD (10), effects which previously had been observed in adults $(8,9)$.

It has long been known that insulin is anabolic with regard to protein metabolism. This is caused by inhibiting protein breakdown, rather than by stimulating protein synthesis (1416). Part of the protein-wasting effect of glucocorticoids is the result of steroid-induced resistance to the antiproteolytic effect of insulin (17) We hypothesized that insulin treatment during the first few days of treatment with dexamethasone would counteract the well-documented increase in protein degrada- 
tion. Furthermore, we hypothesized that the rate of weight gain would be positively influenced by the addition of insulin to the dexamethasone treatment of preterm infants with CLD.

Because studies have shown that the effect of dexamethasone is maximal during the first week of treatment $(5,10)$, we administered insulin during the first $4 \mathrm{~d}$ only. We evaluated plasma C-peptide levels daily to determine whether the endogenous insulin production was suppressed by the administration of exogenous insulin.

\section{METHODS}

Patients. This study was approved by the medical ethics committee of the Academic Hospital Rotterdam and Sophia Children's Hospital. Informed consent was obtained from the parents of 12 infants who could not be weaned from a ventilator on which they had been dependent since birth and who were selected for dexamethasone treatment by the attending neonatologist. Patients excluded from this study were those infants suspected of having contracted sepsis at the beginning of dexamethasone treatment, as well as any infants who had a metabolic disease or liver failure. Dexamethasone was administered i.v. in two equal doses per day, totaling $0.5 \mathrm{mg} / \mathrm{kg} / \mathrm{d}$ for the first $3 \mathrm{~d}, 0.3 \mathrm{mg} / \mathrm{kg} / \mathrm{d}$ for the second $3 \mathrm{~d}$, then gradually tapering off to alternate days of $0.1 \mathrm{mg} / \mathrm{kg} / \mathrm{d}$ by $\mathrm{d} 21$, and stopped at d 28 [adapted from Avery et al. (1)]. During the first $4 \mathrm{~d}$ of dexamethasone treatment, short-acting insulin (Actrapid HM, Novo, NOVONORDISC, Pharma Bv, Alpher a/d Rýn, The Netherlands) was continuously administered i.v. (0.5 IU insulin $/ \mathrm{kg} / \mathrm{d}$ in seven patients and $1.0 \mathrm{IU}$ insulin $/ \mathrm{kg} / \mathrm{d}$ in five patients), beginning with the first dose of corticosteroids.

Weight was measured daily on an electronic scale with a resolution of $5 \mathrm{~g}$. Average daily weight gain was calculated from daily weight changes in the week before the start of dexamethasone therapy and in the three subsequent weeks, and expressed as grams per kilogram per day.

According to the feeding protocol of the neonatal unit, all patients were parenterally fed during the first $7 \mathrm{~d}$ of life [dextrose 10\%, amino acids (Primene 10\%, Clintec Benelux, Brussels, Belgium), and lipids (Intralipid 20\%, Kabi Pharmacia, Stockholm, Sweden)], after which oral feeding was gradually introduced in the second week (Nenatal, Nutricia Zoetermeer, The Netherlands).

Leucine turnover studies. Patients were studied before the start of dexamethasone treatment and on d 2, 4, and 7 afterward. Leucine turnover studies were conducted by i.v. administration of $\left[1-{ }^{13} \mathrm{C}\right]$ leucine $(99 \%$ enriched, Isotec Inc., Miamisburg, OH, U.S.A.) $2 \mathrm{mg} / \mathrm{kg}$ bolus and $2 \mathrm{mg} / \mathrm{kg} / \mathrm{h}$ maintenance dose for $3 \mathrm{~h}$. The tracer was given with the use of a Harvard infusion pump (model M22; Harvard Apparatus Co. Inc., South Natick, MA, U.S.A.). Blood samples were drawn before the administration of the stable isotope, at $30 \mathrm{~min}$ before the end, and at the end of the $\left[1-{ }^{13} \mathrm{C}\right]$ leucine administration. Blood was stored immediately at $0^{\circ} \mathrm{C}$ and centrifuged at $3000 \mathrm{rpm}$ within $15 \mathrm{~min}$, and plasma was then stored at $-80^{\circ} \mathrm{C}$. Per study day, three blood samples of $0.5 \mathrm{~mL}$ were taken. In total, $6 \mathrm{~mL}$ blood was taken per patient during the entire study.
Enrichment of $\alpha$-ketoisocaproic acid, which reflects the intracellular enrichment of leucine $(18,19)$, was determined as described previously (10). In brief, plasma is deproteinized with sulfosalicylic acid, and the $\alpha$-ketoacids are reacted with phenylenediamine to form quinoxalinol derivatives. The quinoxalinol derivatives are extracted with a mixture of dichloromethane/hexane, dried, and silylated with $\mathrm{N}$-methyl- $\mathrm{N}$-(tertbutyldimethylsilyl)-trifluoracetamide (MTBSTFA, Pierce; Omnilabo, Breda, The Netherlands) to form the butyldimethylsilylquinoxalinol derivatives. Analyses were performed by injecting $1 \mu \mathrm{L}$ with a split ratio of 50:1 on a fused silica capillary column of $25 \mathrm{~m} \times 0.22 \mathrm{~mm}$, coated with $0.11 \mathrm{~m}$ HT5 (SGE, Victoria, Australia). Plasma enrichment of $\left[1-{ }^{13} \mathrm{C}\right]-$ ketoisocaproic acid was analyzed on a Hewlett-Packard 5890 gas chromatograph coupled to a JMS-DX303 mass spectrometer (Jeol LTD, Tokyo, Japan) in electron impact ionization mode with an interface temperature of $280^{\circ} \mathrm{C}$ and a source temperature of $200^{\circ} \mathrm{C}$. Selected ion monitoring was performed at mass 259 and 260 for natural and enriched ketoisocaproic acid. The SD was $0.2 \mathrm{~mol} \%$ (range, $0-20 \mathrm{~mol} \%$ ) for $\left[1-{ }^{13} \mathrm{C}\right]$ ketoisocaproic acid; a concentration effect was not observed for the measured mole percent enrichment and the amount injected. Background enrichment at $\mathrm{d} 4$ and 7 was not different from that on $\mathrm{d} 2$, so recycling of infused tracer was negligible.

Leucine turnover rates were calculated as described before, using the reciprocal pool model (10). Leucine turnover was calculated according to the following equation:

$$
Q_{L}=\left[\left(I E_{\text {infusate }} / I E_{\text {plasma }}\right)-1\right] \times I_{L}
$$

where $I E_{\text {infusate }}$ is the isotopic enrichment of the infusate, $I E_{\text {plasma }}$ is the isotopic enrichment of $\alpha\left[1-{ }^{13} \mathrm{C}\right]$ ketoisocaproic acid in plasma and $I_{\mathrm{L}}$ the infusion rate of $\left[1-{ }^{13} \mathrm{C}\right]$ leucine in micromoles per kilogram per hour. In a steady state, leucine that leaves the pool should equal leucine that enters the pool. Leucine can enter the pool through the diet $(I)$ and from breakdown of protein $(B)$, and leave the pool via protein synthesis $(S)$ and excretion $(E)$. Breakdown was therefore calculated according to the following equation:

$$
Q=B+I
$$

Urine was collected using adhesive bags to calculate the nitrogen balance. Nitrogen balance is expressed as grams of protein per kilogram per day, assuming that $6.25 \mathrm{~g}$ protein contains $1 \mathrm{~g}$ nitrogen.

On each study day, plasma C-peptide levels as an indicator of endogenous insulin production were determined using a C-peptide ${ }^{125}$ I-RIA kit (Incstar Corporation, Stillwater, MN, U.S.A.).

Statistical analysis. All data are expressed as mean \pm SEM unless otherwise stated. Statistical analysis was performed with the use of one-way ANOVA with repeated measurements. Differences between two study days were considered to be statistically significant at $p \leq 0.05$ (two-sided).

\section{RESULTS}

The average birth weight of the participating infants was $841 \mathrm{~g}$ (range, 535-1140 g), with a gestational age of $26.7 \mathrm{wk}$ 
Table 1. Clinical characteristics of the individual preterm infants with CLD receiving dexamethasone therapy

\begin{tabular}{|c|c|c|c|c|c|c|}
\hline Patient & $\begin{array}{l}\text { Insulin dose } \\
\text { (IU) }\end{array}$ & $\begin{array}{l}\text { Gestational age } \\
\text { (wk) }\end{array}$ & $\begin{array}{l}\text { Birth weight } \\
\text { (g) }\end{array}$ & AGA/SGA & $\begin{array}{l}\text { Age at time } \\
\text { of study } \\
\text { (d) }\end{array}$ & $\begin{array}{c}\text { Weight at time } \\
\text { of study } \\
(\mathrm{g})\end{array}$ \\
\hline 1 & 0.5 & 28.3 & 755 & SGA & 16 & 865 \\
\hline 3 & 0.5 & 24.7 & 735 & AGA & 10 & 815 \\
\hline 4 & 0.5 & 28.0 & 700 & SGA & 20 & 910 \\
\hline 5 & 0.5 & 25.3 & 685 & AGA & 18 & 675 \\
\hline 8 & 1 & 27.2 & 1125 & AGA & 33 & 1380 \\
\hline 9 & 1 & 25.7 & 1000 & AGA & 14 & 1225 \\
\hline 10 & 1 & 27.3 & 1075 & AGA & 13 & 1105 \\
\hline 11 & 1 & 25.3 & 640 & SGA & 11 & 710 \\
\hline 12 & 1 & 27.7 & 535 & SGA & 21 & 635 \\
\hline
\end{tabular}

No significant differences between the 0.5 IU and the 1.0 IU group. AGA, appropriate for gestational age; SGA, small for gestational age.

(range, 25.3-28.3 wk). The average postnatal age at start of the corticosteroid therapy was $17 \mathrm{~d}$ (range, 10-33 d). Clinical characteristics of the individual patients are given in Table 1. Because of the improvement of the clinical status of the children, the attending neonatologist was able to increase protein and energy intake significantly on $\mathrm{d} 7$ compared with $\mathrm{d}$ 0 . No statistically significant differences were found between protein or energy intakes on d 0 compared with d 2 or 4 (Table 2).

Insulin did not prevent the drop in weight gain during the first week of dexamethasone treatment, as we have observed earlier (10). The weight gain rates were determined according to intrauterine values (20) from the third week of dexamethasone treatment onward. Weight gain rates in the infants receiving 0.5 versus 1.0 insulin were not significantly different (Fig. 1).

Glucose levels remained between 3.5 and $7 \mathrm{mM}$ during insulin treatment from $\mathrm{d} 1$ to 4 without the need to infuse extra glucose. No difference was found between infants treated with 0.5 or $1.0 \mathrm{IU}$ insulin $/ \mathrm{kg} / \mathrm{d}$. After stopping insulin administration on $\mathrm{d} 4$, some patients had transiently elevated blood glucose levels, as are often observed in patients treated with dexamethasone without providing insulin. Insulin administration did not have to be restarted in any patient.

No differences in leucine metabolism were found between the infants treated with 0.5 versus $1.0 \mathrm{IU}$ insulin $/ \mathrm{kg} / \mathrm{d}$ (data not shown). Inasmuch as there were no differences in birth weight, gestational age, study age, and weight, the results were therefore combined. Whole-body leucine turnover and breakdown rates are shown in Figure 2.

Leucine turnover was not significantly different among d 0 $(337 \pm 41 \mu \mathrm{mol}$ leucine $/ \mathrm{kg} / \mathrm{h}), \mathrm{d} 2$ (288 $\pm 27 \mu \mathrm{mol}$ leucine/ $\mathrm{kg} / \mathrm{h}), \mathrm{d} 4(302 \pm 22 \mu \mathrm{mol}$ leucine $/ \mathrm{kg} / \mathrm{h})$, and $\mathrm{d} 7$ (321 \pm 21 $\mu \mathrm{mol}$ leucine $/ \mathrm{kg} / \mathrm{h})$. Leucine breakdown also was not different among study days $(272 \pm 22 \mu \mathrm{mol}$ leucine $/ \mathrm{kg} / \mathrm{h}$ on $\mathrm{d} 0,225 \pm$ $22 \mu \mathrm{mol}$ leucine $/ \mathrm{kg} / \mathrm{h}$ on d 2, $231 \pm 21 \mu \mathrm{mol}$ leucine $/ \mathrm{kg} / \mathrm{h}$ on $\mathrm{d} 4$, and $242 \pm 18 \mu \mathrm{mol}$ leucine $/ \mathrm{kg} / \mathrm{h}$ on $\mathrm{d} 7$ ).

We were able to obtain a reliable 24 -h urine collection from only four infants on $\mathrm{d} 0$ and $\mathrm{d} 2$, because of the small size of our subjects. In those four infants, the net protein balance remained positive and significantly different from zero despite the dexamethasone treatment $(1.16 \pm 0.55 \mathrm{~g} / \mathrm{kg} / \mathrm{d})$.

In our previous study (10), we found a negative nitrogen balance during treatment with high dosages of dexamethasone. Despite the infants' severe clinical condition, net protein balance was also positive before the start of the dexamethasone $(1.94 \pm 0.97 \mathrm{~g} / \mathrm{kg} / \mathrm{d})$.

Endogenous insulin production was measured via plasma C-peptide levels. Despite exogenous insulin administration, endogenous insulin production was not suppressed either in infants receiving $0.5 \mathrm{IU}$ insulin $/ \mathrm{kg} / \mathrm{d}$ or in those receiving 1.0 IU insulin $/ \mathrm{kg} / \mathrm{d}$. C-peptide concentrations increased significantly after cessation of the exogenous insulin administration (Fig. 3).

\section{DISCUSSION}

In this study, we found no increase in either leucine turnover or breakdown during a combined infusion of high-dose corticosteroids and insulin. This finding contrasts with that of a study we previously conducted in infants with bronchopulmonary dysplasia who were treated with dexamethasone without insulin (10); after $4 \mathrm{~d}$ of high-dose corticosteroids, the infants displayed a significant increase in protein breakdown.

We did not include a control group of infants who did not receive insulin for the following reasons. First, multiple studies have shown that glucocorticosteroids increase proteolysis in animal models $(12,13$,), adults $(6-8,14)$, and preterm infants $(5,10)$. Second, the number of infants who receive dexamethasone treatment for CLD is small, and this group of infants is

Table 2. Protein and energy intakes

\begin{tabular}{ccc}
\hline & $\begin{array}{c}\text { Protein intake } \\
(\mathrm{g} / \mathrm{kg} / \mathrm{d})\end{array}$ & $\begin{array}{c}\text { Energy intake } \\
(\mathrm{kcal} / \mathrm{kg} / \mathrm{d})\end{array}$ \\
\hline Day & $2.25 \pm 0.3$ & $88.7 \pm 8.7$ \\
Day 2 & $2.32 \pm 0.3$ & $90.5 \pm 6.9$ \\
Day 4 & $2.74 \pm 0.2$ & $100.4 \pm 6.9$ \\
Day 7 & $3.16 \pm 0.3^{*}$ & $118.4 \pm 10.0^{*}$ \\
\hline
\end{tabular}

Values reported as mean \pm SEM.

* Statistically significant difference at $p<0.05$ from d 0 . 


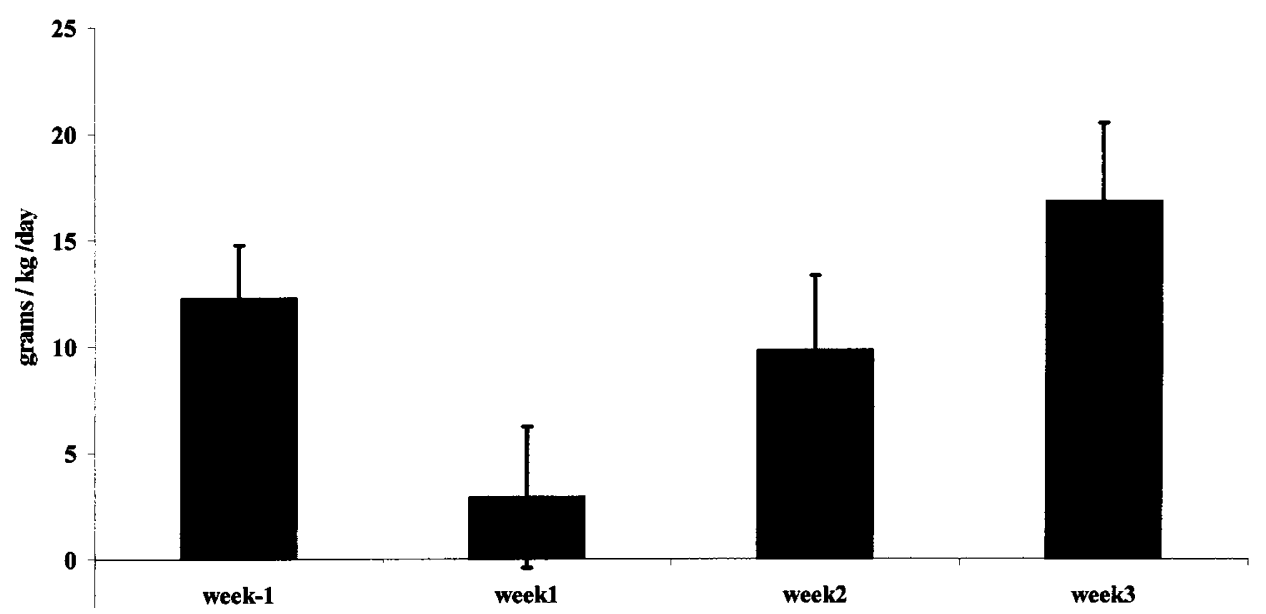

Fig. 1. Average daily weight gain in grams per kilogram per day ( \pm SEM) 1 wk before dexamethasone and in the first, second, and third weeks after dexamethasone treatment. ${ }^{*} p<0.05$ significant difference from d 0 .

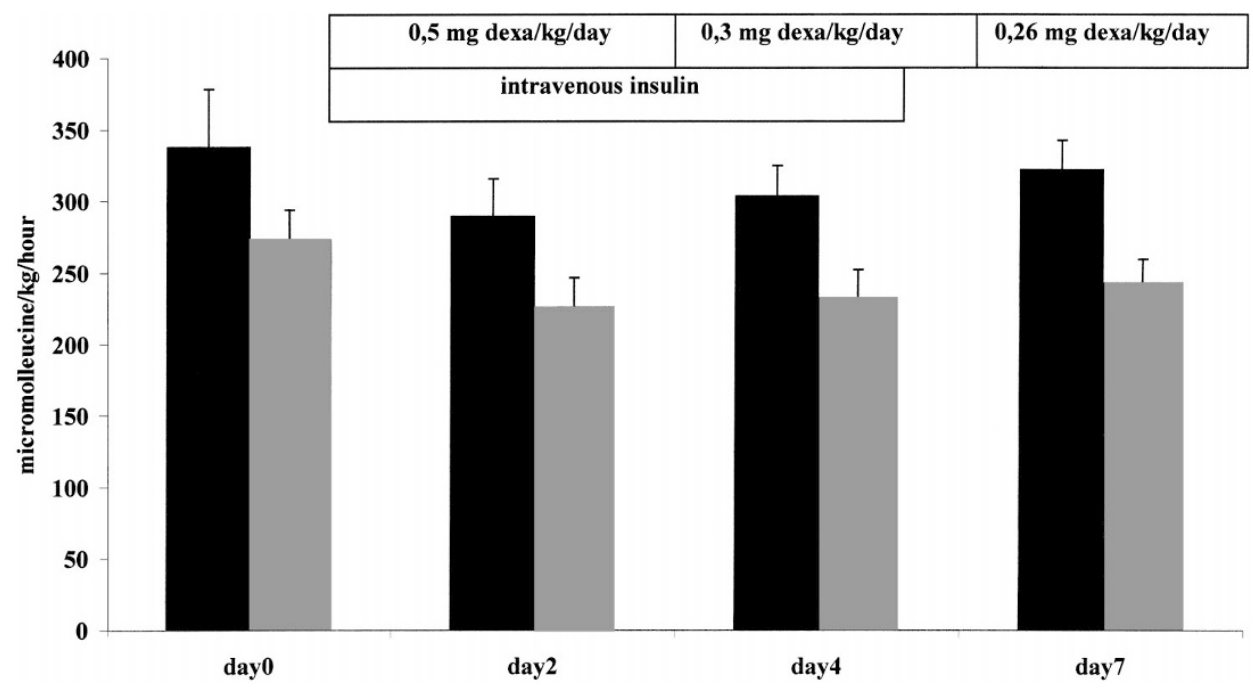

Fig. 2. Leucine turnover (black bars) and breakdown (gray bars) on d 0, 2, 4, and 7 after start of dexamethasone therapy. Leucine data are presented in micromoles per kilogram per hour (mean \pm SEM).

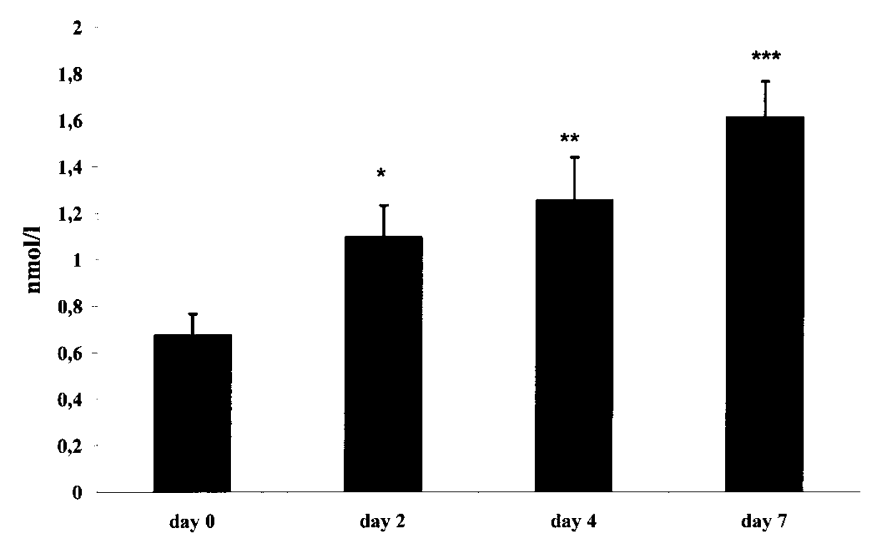

Fig. 3. Average plasma C-peptide levels in nanomoles per liter (mean \pm SEM). $* p<0.05 ; * * p<0.01 ; * * p<0.001$ compared with $\mathrm{d} 0$.

very hard to study. The addition of a control group either would have reduced the number of infants receiving insulin treatment or considerably prolonged our study, which encompassed nearly $2.5 \mathrm{y}$. Changes in treatment protocols over a period of several years, which are inevitable in a rapidly developing subspecialty like neonatology, increase the variability in the results, which are already significant. In Table 3, we compare the results of this study with a previous study in which leucine kinetics were studied during the same dexamethasone treatment, but without insulin administration. Although there is a difference in birth weight and postnatal age at time of study, the leucine turnover and breakdown on $\mathrm{d} 0$ are in the same range. However, on d 4, a significant increase in protein breakdown was measured in the infants studied by van Goudoever et al. (10). This was not present in the group with steroids and insulin.

In this study we chose to form two subgroups receiving either $0.5 \mathrm{IU}$ or $1.0 \mathrm{IU}$ insulin $/ \mathrm{kg} / \mathrm{d}$. Those dosages were chosen arbitrarily, inasmuch as no previous studies have been performed with the combination therapy of dexamethasone and insulin. However, in hyperglycemic infants receiving total parenteral nutrition, insulin doses up to $2.8 \mathrm{IU} / \mathrm{kg} / \mathrm{d}$ have been used (21), and in a study with four clinically stable, preterm infants, a dosage of $1.2 \mathrm{IU} / \mathrm{kg} / \mathrm{d}$ reduced proteolysis, although protein synthesis decreased to the same extent, resulting in no net protein gain (22). To avoid an increase in glucose intake, 
Table 3. Comparison of the present study data with a previous study in infants with only dexamethasone treatment (10)

\begin{tabular}{lccccccc}
\hline \multicolumn{1}{c}{ Treatment } & $\begin{array}{c}\text { Birth weight } \\
(\mathrm{g})\end{array}$ & $\begin{array}{c}\text { Gestational age } \\
(\mathrm{wk})\end{array}$ & $\begin{array}{c}\text { Age at study } \\
(\mathrm{d})\end{array}$ & $\begin{array}{c}\text { Turnover } \\
\mathrm{d} 0\end{array}$ & $\begin{array}{c}\text { Turnover } \\
\mathrm{d} 4\end{array}$ & $\begin{array}{c}\text { Breakdown } \\
\mathrm{d} 0\end{array}$ & $\begin{array}{c}\text { Breakdown } \\
\mathrm{d} 4\end{array}$ \\
\hline Dexa and insulin & $841 \pm 202$ & $26.7 \pm 1.2$ & $17.3 \pm 6.4$ & $337 \pm 143$ & $302 \pm 73$ & $272 \pm 76$ & $231 \pm 70$ \\
Dexa only & $1100 \pm 300$ & $27.5 \pm 2.0$ & $24.7 \pm 12.4$ & $302 \pm 52$ & $376 \pm 85^{*}$ & $207 \pm 54$ & $272 \pm 75^{*}$ \\
\hline
\end{tabular}

Dexa and insulin, data from present study; Dexa only, data from van Goudoever et al, 1994.

Turnover and breakdown are leucine in micromoles per kilogram per hour. All data are mean $\pm \mathrm{SD}$. * indicates a statistical significant difference from d 0 values at $p \leq 0.05$.

we chose to randomly assign the infants to either $0.5 \mathrm{IU}$ or 1.0 $\mathrm{IU}$ insulin $/ \mathrm{kg} / \mathrm{d}$. The apparent absence of a dose response in leucine kinetics in response to $0.5 \mathrm{IU}$ versus $1.0 \mathrm{IU}$ insulin $/ \mathrm{kg} / \mathrm{d}$ may be because of the number of infants studied.

The fact that insulin reduces proteolysis has been demonstrated in a number of studies $(17,22)$. Administration of insulin and glucose partially blocked branched-chain $\alpha$-ketoacid dehydrogenase activity. Smith et al. (13) found that protein catabolism is exaggerated in diabetic rats compared with normal rats. Because the major effect of dexamethasone treatment is proteolysis, the choice for concomitant insulin treatment was an obvious one.

Our results show that with simultaneously administration of insulin and dexamethasone, there is no increase in protein breakdown. After discontinuation of insulin we did not see an increase in protein breakdown. The reason for this could be that on $\mathrm{d} 7$ the endogenous insulin production has increased more than 2-fold compared with baseline (Fig. 3). Second, the dose of dexamethasone has been decreased by $50 \%$ on $\mathrm{d} 7$.

We did not measure leucine oxidation, so we are not able to calculate whether protein synthesis was affected. However, in a small subgroup of infants, we found a positive net protein balance, indicating that the overall effect of insulin in infants treated with dexamethasone was anabolic. This result stands in contrast to the weight gain rates we observed. Contrary to the leucine results, and similar to our previous study in infants receiving dexamethasone without insulin, weight gain rates decreased during high dosages of dexamethasone and insulin, whereas they normalized at the end of the tapered treatment. The reasons for the discrepancy in leucine results and nitrogen balances versus weight gain rates are not clear. It may be that leucine is not a very good indicator of whole-body protein metabolism, as leucine is an essential amino acid that is relatively abundant in formula, or that the small number of infants in whom we were able to obtain reliable urinary nitrogen excretion data did not react as a representative subgroup. Another explanation could be that dexamethasone has an effect on body composition and weight gain, and therefore is not a good measure for growth in this situation. There was, however, no effect on daily fluid balances that could explain the reduced weight gain during high-dose dexamethasone (data not shown)

Theoretically, exogenous insulin administration could suppress endogenous insulin production. To be sure that endogenous insulin production was not suppressed by exogenous insulin administration, we measured plasma C-peptide levels. Although plasma-measured C-peptide levels are less accurate than computerized compartmental analysis of C-peptide concentration in predicting prehepatic C-peptide production (23), it appeared that even during exogenous insulin administration, the C-peptide levels increased, indicating that endogenous insulin production increased. This means that there are no indications that endogenous insulin production is suppressed by the doses of insulin used in this study.

Because protein breakdown is accelerated by corticosteroids, we believe that blocking such an increase in these infants is preferable to increasing their already high protein synthesis rate.

Other strategies to counteract the steroid-induced increase in protein breakdown are the use of rhGH or IGF. IGF has failed to reverse corticosteroid-induced protein breakdown in piglets, and in a pilot study, GH did not prevent protein breakdown in bronchopulmonary dysplasia-afflicted infants with dexamethasone $(24,25)$. In the past few years, studies have been published on adult patients treated with corticosteroids long term, whose protein balance showed an improvement after providing a therapy combining corticosteroids with rhGH $(26-28)$. This effect stemmed solely from increased protein synthesis; protein breakdown was not affected. Combination of rhGH with IGF-I appeared to result in a substantially more positive protein balance than either one alone (29). However, data are conflicting because rhGH did not modify the protein breakdown in rats given dexamethasone (30). In infants, protein turnover (i.e. protein breakdown and synthesis) occurs at a much higher level than in children and adults (10). Furthermore, as recent publications on the use of rhGH in critically ill adults have shown a 2-fold increase in mortality rates (31), the use of rhGH in critically ill preterm infants should not be advocated in the absence of a thorough examination of the effect of rhGH in such patients.

During our study, as the clinical status of most of the patients improved, their nutrient intake changed; total caloric and oral protein intake increased, and parenteral protein intake declined. There were, however, no significant differences in either protein or energy intake between $\mathrm{d} 0$ and 4 , the period in which insulin was administered.

In conclusion, the results of this study show that during combined insulin and steroid treatment in preterm infants with CLD, leucine kinetics remain unchanged. This was, however, not accompanied by an increase in weight gain, so that the anabolic effect of insulin in preterm infants receiving dexamethasone has yet to be established.

Acknowledgment. The authors thank L. Loddeke for her expert editorial help.

\section{REFERENCES}

1. Avery G, Fletcher A, Kaplan M, Brudno D 1985 Controlled trial of dexamethasone in respirator-dependent infants with bronchopulmonary dysplasia. Pediatrics 75:106111

2. Yeh TF, Lin YJ, Hsieh WS, Lin CH, Chen JY, Kao HA, Chien CH 1997 Early postnatal dexamethasone therapy for the prevention of chronic lung disease in preterm 
infants with respiratory distress syndrome: a multicenter clinical trial. Pediatrics 100(4):E3

3. Cummings JJ, Eugenio DB, Gross SJA 1989 Controlled trial of dexamethasone in preterm infants at high risk for bronchopulmonary dysplasia. $\mathrm{N}$ Engl J Med 320:1505-1510

4. Skinner AM, Battin M, Solimano A, Daaboul J, Kitson HF 1997 Growth and growth factors in premature infants receiving dexamethasone for bronchopulmonary dysplasia. Am J Perinatol14:539-546

5. Brownlee K, Ng P, Henderson M, Smith M, Green J, Dear P 1992 Catabolic effect of dexamethasone in the preterm baby. Arch Dis Child 67:1-4

6. Shamoon H, Soman V, Sherwin S 1980 The influence of acute physiological increments of cortisol on fuel metabolism and insulin binding to monocytes in normal humans. J Clin Endocrinol Metab 50:495-501

7. Simmons P, Miles J, Gerich J, Haymond M 1984 Increased proteolysis: an effect of increases in plasma cortisol within the physiologic range. J Clin Invest 73:412-420

8. Horber F, Marsh M, Haymond M 1991 Differential effects of prednisone and growth hormone on fuel metabolism and insulin antagonism in humans. Diabetes 40:141-144

9. Beaufrere B, Horber F, Schwenk F, Marsh M, Matthews D, Gerich J, Haymond M 1989 Glucocorticoids increase leucine oxidation and impair leucine balance in humans Am J Physiol 257:E712-E721

10. Van Goudoever JB, Wattimena JDL, Carnielli VP, Sulkers EJ, Degenhart HJ, Sauer PJJ 1994 Effect of dexamethasone on protein metabolism in infants with bronchopulmonary dysplasia. J Pediatr124:112-118

11. Darmoun D, Matthews D, Bier D 1988 Physiological hypercortisolemia increases proteolysis, glutamine and alanine production. Am J Physiol 255:E366-E373

12. McGrath JA, Goldspink DF 1982 Glucocorticoid action on protein synthesis and protein breakdown in isolated skeletal muscles. Biochem J 206:641-645

13. Smith OLK, Wong. CY, Gelfland RA 1990 Influence of glucocorticoids on skeletal muscle proteolysis in normal and diabetic-adrenalectomized eviscerated rats. Metabolism 39:641-646

14. Gelfland RA, Barrett EJ 1987 Effect of physiologic hyperinsulinemia on skeletal muscle protein synthesis and breakdown in man. J Clin Invest 80:1-6

15. Tessari P, Inchiostro S, Biolo G, Trevisan R, Fantin G, Marescotti MC, Lori E, Tiengo A, Crepaldi G 1987 Differential effects of hyperinsulinemia and hyperaminoacidemia on leucine-carbon metabolism in vivo. J Clin Invest 79:1062-1069

16. Castellino P, Luzi L, Del Prato S, DeFronzo RA 1990 Dissociation of the effects of epinephrine and insulin on glucose and protein metabolism. Am J Physiol E117-E124

17. Zimmerman T, Horber F, Rodriguez N, Schwenk F, Haymond M 1989 Contribution of insulin resistance to catabolic effect of prednisone on leucine metabolism in humans. Diabetes 38:1228-1244
18. Matthews DE, Schwartz HP, Yang RD, Motil KJ, Young VR, Bier DM 1982 Relationship of plasma leucine and alpha-ketoisocaproate during a $1-\left[1-{ }^{13} \mathrm{C}\right]$ leucine infusion in man: a method for measuring human intracellular leucine tracer enrichment. Metab Clin Exp 31:1105-1112

19. Schwenk WF, Beaufrere B, Haymond MW 1985 Use of reciprocal pool specific activities to model leucine metabolism in humans. Am J Physiol 246:E646-E650

20. Usher RH, Mclean F 1969 Intrauterine growth of life-born Caucasian infants at sea level: standards obtained from measurements in 7 dimensions of infants born between 25 and 44 weeks of gestation. J Pediatr 74:901-910

21. Kanarek KS, Santeiro ML, Malone JI 1991 Continuous infusion of insulin in hyperglycemic low-birth weight infants receiving parenteral nutrition with and without lipid emulsion. J Parenter Enteral Nutr 15:417-420

22. Poindexter B, Karn C, Denne S 1998 Exogenous insulin reduces proteolysis and protein synthesis in extremely low birth weight infants. J Pediatr 132:948-953

23. Polonsky K, Frank B, Pugh W, Addis A, Karrison T, Meier P, Tager H, Rubenstein A 1986 The limitation to and valid use of C-peptide as a marker of the secretion of insulin. Diabetes 35:379-386

24. Hellstern G, Reyngoud DJ, Stellard F, Okken A 1996 Insulin-like growth factor has failed to reverse corticosteroid-induced protein catabolism in growing piglets. Pediatr Res 39:421-426

25. Tonini T, Pahor T, Colonna F, Vonderweid U 1997 Growth hormone does not prevent catabolic side effects of dexamethasone in extremely low birth weight preterm infants with bronchopulmonary dysplasia: a pilot study. J Pediatr Endocrinol Metab 10:291294

26. Horber F, Haymond M 1990 Human growth hormone prevents the protein catabolic side effects of prednisone in humans. J Clin Invest 86:265-272

27. Bennet W, Haymond M 1992 Growth hormone and lean tissue catabolism during long term glucocorticoid treatment. Clin Endocrinol 36:161-164

28. Marcus R, Butterfield G, Holloway L, Gilliland L, Baylink DJ, Hintz RL, Sherman BM 1990 Effects of short term administration of recombinant human growth hormone to elderly people. J Clin Endocrinol Metab 70:519-527

29. Kupfer RS, Underwood LE, Baxter RC, Clemmons DR 1993 Enhancement of the anabolic effects of growth hormone and insulin-like growth factor by use of both agents simultaneously. J Clin Invest 91:391-396

30. Lo HC, Hinton PS, Yang H, Unterman TG, Ney DM 1996 Insulin-like growth factor-I but not growth hormone attenuates dexamethasone-induced catabolism in parenterally fed rats. J Parenter Enteral Nutr 20:171-177

31. Takala J, Ruokonen E, Webster NR, Nielsen MS, Zandstra DF, Vundelinckx G, Hinds 1999 Increased mortality associated with growth hormone treatment in critically ill adults. N Engl J Med 341:785-792 